\title{
Epstein Barr virus-associated lymphoproliferative diseases: the virus as a therapeutic target
}

\author{
Eric Tse and Yok-Lam Kwong
}

Epstein Barr virus (EBV)-associated lymphoproliferative diseases (LPDs) express all EBV latent antigens (type III latency) in immunodeficient patients and limited antigens (type I and II latencies) in immunocompetent patients. Post-transplantation lymphoproliferative disease (PTLD) is the prototype exhibiting type III EBV latency. Although EBV antigens are highly immunogenic, PTLD cell proliferation remains unchecked because of the underlying immunosuppression. The restoration of anti-EBV immunity by EBV-specific T cells of either autologous or allogeneic origin has been shown to be safe and effective in PTLDs. Cellular therapy can be improved by establishing a bank of human leukocyte antigen-characterized allogeneic EBV-specific T cells. In EBV+ LPDs exhibiting type I and II latencies, the use of EBV-specific T cells is more limited, although the safety and efficacy of this therapy have also been demonstrated. The therapeutic role of EBV-specific T cells in EBV+ LPDs needs to be critically reappraised with the advent of monoclonal antibodies and other targeted therapy. Another strategy involves the use of epigenetic approaches to induce EBV to undergo lytic proliferation when expression of the viral thymidine kinase renders host tumor cells susceptible to the cytotoxic effects of ganciclovir. Finally, the prophylactic use of antiviral drugs to prevent EBV reactivation may decrease the occurrence of EBV+ LPDs.

Experimental \& Molecular Medicine (2015) 47, e136; doi:10.1038/emm.2014.102; published online 23 January 2015

\section{INTRODUCTION}

Epstein Barr virus (EBV) is the first human virus isolated from a neoplastic disorder. ${ }^{1}$ EBV infects most humans. The initial infection may be asymptomatic and often occurs in childhood. In older individuals, a more florid clinical syndrome of infectious mononucleosis may occur. ${ }^{2}$ Regardless of the initial manifestation, EBV establishes a lifelong latency in B cells. EBV exists in an episomal form and is not integrated into the host cell genome. ${ }^{2} \mathrm{EBV}$ is involved in numerous malignancies (Table 1), suggesting that it plays an important role in oncogenesis.

During primary infection, EBV enters the oropharyngeal epithelial cells. Viral replication leads to infection of naïve $B$ cells. EBV-infected B cells become lymphoblasts and express the entire EBV latency gene complex, which consists of at least 10 proteins (which include EBNA1, EBNA2, EBNA3, LMP1, LMP2 and BARF1) and two small RNAs (type III latency). ${ }^{3}$ These lymphoblasts are highly immunogenic and are targets of EBV-specific cytotoxic T cells. However, when EBV-infected B cells enter lymphoid follicles, downregulation of these EBV immunogenic proteins occurs, with the expression of three less immunogenic EBV proteins (EBNA1, LMP1 and LMP2) (type II latency) remaining, thereby allowing these EBVinfected B cells to survive. When memory B cells exit lymphoid follicles, they may not express EBV-related proteins (type 0 latency). These memory $B$ cells circulate and re-enter secondary follicles, where they express EBNA1 (type I latency). EBNA1 promotes the replication of the viral episome. ${ }^{4}$ The persistence of EBV-infected B cells of type II latency in these secondary lymphoid tissues, including the tonsils, ${ }^{5}$ promotes the expression of LMP1 and LMP2, which are essential signals for the survival of these circulating EBV-infected memory B cells.

A dominant theory in oncogenesis is that when transformation occurs, neoplastic cells are often arrested at their respective stages of cellular development or maturation. Transcriptional programs are often retained, and phenotypes of these neoplastic cells often resemble those of their normal counterparts. This notion is reflected in the various EBV latency states in EBV-associated malignancies (Table 1).

\section{EBV-ASSOCIATED LYMPHOID MALIGNANCIES}

The number of EBV-associated lymphoid malignancies continues to increase (Table 1), emphasizing the importance of 
Table 1 Epstein Barr virus-associated malignancies

\begin{tabular}{|c|c|c|c|}
\hline Neoplasms & EBV latency & Treatment strategy & $\begin{array}{c}\text { EBV-targeted } \\
\text { therapy }\end{array}$ \\
\hline \multicolumn{4}{|l|}{ Lymphoproliferative diseases } \\
\hline \multicolumn{4}{|l|}{ B cells } \\
\hline Post-transplantation lymphoproliferative disorders & III & $\begin{array}{l}\text { Reduction of immunosuppressive agents; rituximab }+/ \text { - } \\
\text { chemotherapy }\end{array}$ & +++ \\
\hline $\begin{array}{l}\text { Lymphoproliferative diseases associated with primary } \\
\text { immune disorders }\end{array}$ & III & Rituximab $+/$ - chemotherapy & - \\
\hline Lymphomas associated with HIV infections & III & HAART and chemotherapy & - \\
\hline $\begin{array}{l}\text { latrogenic immunodeficiency-associated lymphoproli- } \\
\text { ferative diseases }\end{array}$ & III & $\begin{array}{l}\text { Reduction of immunosuppressive agents; rituximab }+ \text { /- } \\
\text { chemotherapy }\end{array}$ & - \\
\hline EBV+ diffuse large B-cell lymphoma of the elderly & II & Rituximab+CHOP-based chemotherapy & - \\
\hline $\begin{array}{l}\text { Diffuse large B-cell lymphomas, not otherwise } \\
\text { specified }\end{array}$ & II & Rituximab+CHOP-based chemotherapy & ++ \\
\hline Pyothorax-associated lymphoma & III & Rituximab+chemotherapy & - \\
\hline Plasmablastic lymphoma & III & Rituximab+chemotherapy & - \\
\hline Primary effusion lymphoma & I & Rituximab+chemotherapy & - \\
\hline Burkitt lymphoma & I & Intensive chemotherapy & + \\
\hline Hodgkin lymphoma & II & Combination chemotherapy & ++ \\
\hline \multicolumn{4}{|l|}{ T cells } \\
\hline Peripheral T-cell lymphoma, not otherwise specified & II & Chemotherapy & ++ \\
\hline EBV+ lymphoproliferative disorders of childhood & $\mid / I I$ & Chemotherapy & - \\
\hline Chronic active EBV infection (T-cell type) & II & Allogeneic HSCT & - \\
\hline \multicolumn{4}{|l|}{ NK cells } \\
\hline Extranodal NK/T-cell lymphomas, nasal type & II & L-asparaginase-based chemotherapy & ++ \\
\hline Aggressive NK-cell leukemia & II & Chemotherapy & - \\
\hline Chronic active EBV infection (NK-cell type) & II & Allogeneic HSCT & - \\
\hline \multicolumn{4}{|l|}{ Epithelial cancers } \\
\hline Nasopharyngeal cancer & II & Radiotherapy + / - chemotherapy & ++ \\
\hline Lymphoepithelioma-like carcinoma & II & Surgical resection $+/$ - chemotherapy & - \\
\hline Gastric carcinoma & I & Surgical resection $+/$ - chemotherapy & - \\
\hline \multicolumn{4}{|l|}{ Sarcomas and other soft-tissue tumors } \\
\hline $\begin{array}{l}\text { Inflammatory pseudotumor variant of follicular dendritic } \\
\text { cell sarcoma }\end{array}$ & II & Chemotherapy; surgical resection & - \\
\hline HIV-related smooth muscle tumor & III & HAART; surgical resection & - \\
\hline Post-transplantation smooth muscle tumor & III & $\begin{array}{l}\text { Reduction of immunosuppressive agents; surgical } \\
\text { resection }\end{array}$ & - \\
\hline $\begin{array}{l}\text { Congenital immunodeficiency-related smooth muscle } \\
\text { tumor }\end{array}$ & III & Surgical resection & - \\
\hline
\end{tabular}

Abbreviations: EBV, Epstein-Barr virus; HIV, human immunodeficiency virus; NK cells, natural killer cells. +++: most experience; ++: some experience; +: limited experience; -: no experience.

EBV in lymphomagenesis. EBV-associated lymphoproliferative diseases (LPDs) can occur both in immunocompetent and immunocompromised patients. In general, EBV latency states correlate with immunocompetency. EBV type III latency is typically found in LPDs developing in immunodeficient subjects, whereas type I and II latencies are observed in LPDs developing in otherwise immunocompetent subjects.

EBV+ LPDs are highly heterogeneous with regard to pathology and the host background against which the diseases arise. Therefore, treatment strategies are also highly variable. ${ }^{6}$ In general, chemotherapy is the mainstay of treatment in immunocompetent patients. In B-cell malignancies, the antiCD20 monoclonal antibody rituximab is also administered. In immunodeficient patients, efforts to boost the host immunity should be attempted first. In patients with iatrogenic immunosuppression, including autoimmune diseases or after organ allografting, decrease or withdrawal of the immunosuppression constitutes the first-line strategy. If the LPDs fail to regress, the 
use of chemotherapy is indicated. In patients infected with human immunodeficiency virus, highly active antiviral treatment should also be initiated together with chemotherapy. ${ }^{7}$

In patients not responding to these traditional approaches, strategies targeting EBV have been adopted.

\section{CELLULAR THERAPY TARGETING EBV-POSITIVE LPD WITH EBV IN TYPE III LATENCY}

EBV+ neoplastic cells express EBV antigens, which are potential targets for EBV-specific cytotoxic T cells. However, cellular control of EBV-infected cells might not be effective when the immune system is suppressed. The prototype of this condition is post-transplantation lymphoproliferative diseases (PTLDs). This condition can occur after two types of organ transplantation: allogeneic hematopoietic stem cell transplantation (HSCT) and solid organ allografting. After allogeneic HSCT, lymphoid cells are donor-derived. Therefore, PTLDs are of donor lymphoid origin. After solid organ allografting, however, lymphoid cells are derived from the recipient. Hence, PTLDs are of recipient origin.

\section{EBV-POSITIVE PTLD AFTER ALLOGENEIC HSCT}

PTLD is an important complication after allogeneic HSCT. ${ }^{8}$ Risk factors include T-cell depletion, anti-thymocyte globulin use, unrelated or human leukocyte antigen (HLA)-mismatched grafts where T-cell depletion or anti-thymocyte globulin is used, age $\geqslant 50$ years and second HSCT. ${ }^{9}$ The incidence of PTLD peaks at 2-3 months, primarily within the first 6 months post HSCT. ${ }^{9}$ Once developed, PTLD post HSCT is a highly fatal disorder.

Early detection of EBV+ PTLD offers the best possibility of cure. In at-risk patients, monitoring circulating EBV DNA loads enables the early detection of impending EBV+ PTLD. ${ }^{10-12}$ Once an increasing trend of circulating EBV DNA is detected, reduction or withdrawal of immunosuppression should be instituted. ${ }^{8}$ Because most cases of EBV+ PTLD post HSCT involve CD20+ B cells, the preemptive use of rituximab has been shown to abort the development of clinical disease. ${ }^{8,12,13}$ However, when PTLD has developed, the use of rituximab and chemotherapy is less effective. In addition, mortality remains high, suggesting that alternative approaches should be pursued.

The earliest evidence that cellular therapy might be effective for EBV+ PTLD post HSCT was provided by effective disease control with donor lymphocyte infusion, which re-constituted the recipient with donor-derived EBV-reactive $\mathrm{T}$ cells. ${ }^{14}$ However, donor lymphocyte infusion exacerbates graftversus-host disease and is not always practical in severely ill patients. Donor lymphocytes may not be available from matched-unrelated donors and almost certainly cannot be obtained from cord blood donors.

The production of EBV-specific cytotoxic $\mathrm{T}$ cells provides a more specific and potent means of targeting EBV+ PTLD. ${ }^{15}$ Observations in experimental animals showed that $\mathrm{T}$ cells primed against EBV homed to and induced selective regression of EBV-infected B cells. ${ }^{16}$ Furthermore, genetically marked donor-derived EBV-specific $\mathrm{T}$ cells persist for long durations and re-constitute immunity against EBV in recipients of allogeneic HSCT. ${ }^{17}$ These observations ushered in initial trials where HSCT recipients either at risk of or who had actually developed EBV+ PTLD were adoptively transferred with EBV-specific T cells. ${ }^{10,18,19}$ These studies showed that infusions of donor-derived EBV-specific T cells were safe and did not induce graft-versus-host disease. ${ }^{10,18,19}$ These preliminary observations were confirmed by two recent studies. In 101 patients who received donor-derived EBV-specific $\mathrm{T}$ cells prophylactically, none developed PTLD. In 13 patients who were treated for established EBV+ PTLD, 11 responded to EBV-specific T cells. ${ }^{20}$ In 47 patients with established EBV+ PTLD receiving either donor-derived or third-party EBVspecific $\mathrm{T}$ cells, an overall response rate of $68 \%$ was achieved. ${ }^{21}$ Non-respondents harbored EBV strains that differed from those against which the $\mathrm{T}$ cells were primed. In one exceptional case, the PTLD was recipient-derived, so that donor-derived T cells were ineffective owing to HLA restriction. ${ }^{21}$

The key findings of these studies are that the prophylactic use of donor-derived EBV-specific T cells is safe and effective in allogeneic HSCT patients at high-risk of EBV+ PTLD. However, the use of cellular therapy has not been compared with immunotherapy using rituximab, so that its role in prophylactic settings remains undefined. In patients with established EBV+ PTLD, wherein treatment with rituximab and chemotherapy exhibits a low successful outcome, EBV-specific $\mathrm{T}$ cells can also achieve a high response rate.

\section{EBV-POSITIVE PTLD AFTER SOLID ORGAN ALLOGRAFTING}

PTLD after solid organ allografting occurs considerably later, typically after the first year post-transplantation, although cases may occur after many years. ${ }^{22}$ The majority of PTLD cases after solid organ allografting are derived from B-cell lineage, which may or may not be $\mathrm{EBV}+$. A minority of cases is derived from T-cell lineage and is typically EBV-negative.

For EBV+ PTLD after solid organ allografting, a strategy of decreased immunosuppression followed by the use of rituximab and chemotherapy currently serves as the standard approach. ${ }^{23}$ However, not all patients respond, and alternative approaches are needed for refractory patients.

Early observations indicated that cellular therapy might be useful for EBV+ PTLD after solid organ allografting. ${ }^{24,25}$ These studies utilized fully or partially HLA-matched allogeneic $\mathrm{T}$ cells. Later studies examined the use of autologous $\mathrm{T}$ cells. In patients with evidence of active EBV infection, prophylactic infusion of autologous EBV-specific $\mathrm{T}$ cells was safe and appeared to prevent PTLD. ${ }^{26,27}$ The use of autologous EBV-specific $\mathrm{T}$ cells in conjunction with withdrawal of immunosuppression and immunochemotherapy had also been shown to be feasible and effective. ${ }^{27,28}$

Although these studies have indicated that autologous EBV-specific T cells are safe, do not cause graft rejection and may be effective especially when used prophylactically, the 
advent of rituximab and better chemotherapy regimens means that this strategy is only reserved for patients not responding to standard approaches.

\section{THE USE OF THIRD-PARTY EBV-SPECIFIC T CELLS FOR PTLD}

The generation of EBV-specific T cells, either allogeneic or autologous, requires 8-12 weeks. ${ }^{3}$ Therefore, the timely treatment of a patient with active disease not responding to conventional therapy is problematic. Furthermore, in cord blood or matched-unrelated donor HSCT, donor-derived $\mathrm{T}$ cells are generally not available. In patients after solid organ allografting treated with immunosuppression, the collection of enough autologous $\mathrm{T}$ cells may not always be feasible.

The use of third-party partially HLA-matched EBV-specific $\mathrm{T}$ cells has been explored. ${ }^{25}$ In an early study, eight patients received EBV-specific T cells selected on a best HLA-match basis, with three patients achieving a complete remission..$^{29} \mathrm{~A}$ multicenter study examined 33 patients treated with the same strategy. The overall response rate was $52 \%$ at 6 months. ${ }^{30}$ Similarly, third-party EBV-specific T cells have also been used successfully in PTLD after cord blood transplantation, ${ }^{31}$ wherein donor-derived $\mathrm{T}$ cells could not be obtainable.

The logistics of third-party EBV-specific T cells has recently been simplified by the establishment of a bank of HLA-typed allogeneic EBV-specific $\mathrm{T}$ cells using good manufacturing practice standards. ${ }^{32}$ The clinical utility of such a bank remains to be defined.

\section{CELLULAR THERAPY TARGETING EBV+ LPD WITH EBV OF TYPE I AND II LATENCIES}

In conditions other than organ allografting where severe immunosuppression is not involved, EBV is present in type I and II latencies. Although some EBV antigens are expressed, neoplastic cells might have evaded the innate host immune response. Adoptive transfer of a population of EBV-reactive cytotoxic $\mathrm{T}$ cells may potentially provide cellular control of the neoplastic cells.

In LPD with EBV of type I and II latencies, only a limited number of EBV antigens are expressed on the neoplastic cells. Therefore, the efficacy of EBV-specific T cells is not expected to be as good as for PTLD. Experiments in vitro had shown that cloning of T cells reactive to LMP1 and LMP2, which are generally expressed in type II latency in Hodgkin lymphoma, could be achieved. ${ }^{33}$ The clinical feasibility of such an approach was subsequently demonstrated, where autologous EBV-specific T cells generated ex vivo from patients with EBV+ Hodgkin lymphoma were shown to persist to up to 13 weeks in vivo. ${ }^{18}$ These observations were later confirmed in a larger number of patients, ${ }^{34}$ suggesting that autologous EBV-specific $\mathrm{T}$ cells is potentially effective in selected patients with relapsed $\mathrm{EBV}+$ Hodgkin lymphoma.

In chronic active EBV infection, which is another disease that typically involves EBV in type II latency, the infusion of autologous EBV-specific T cells led to an objective response in four of five patients. ${ }^{35}$

More recently, the above observations were replicated in patients with EBV+ lymphomas of various histopathologic

Table 2 Cellular therapies for Epstein Barr virus-associated lymphoproliferative diseases

\begin{tabular}{|c|c|c|c|}
\hline $\begin{array}{l}\text { Type of cellular } \\
\text { therapy }\end{array}$ & Disease & Advantages & Limitations \\
\hline DLI & PTLD after allogeneic HSCT & $\begin{array}{l}\text { Available from most sibling donors } \\
\text { Complicated manufacturing process } \\
\text { not required }\end{array}$ & $\begin{array}{l}\text { Development of GVHD } \\
\text { Generally not available from MUD and UCB }\end{array}$ \\
\hline $\begin{array}{l}\text { Donor EBV-specific } \\
\text { T cells }\end{array}$ & PTLD after allogeneic HSCT & $\begin{array}{l}\text { Available from most sibling donors } \\
\text { Not associated with GVHD }\end{array}$ & $\begin{array}{l}\text { Generally available from MUD and UCB } \\
\text { Complicated and time-consuming process of } \\
\text { manufacturing EBV-specific cytotoxic T cells } \\
\text { from individual donors }\end{array}$ \\
\hline $\begin{array}{l}\text { Autologous EBV- } \\
\text { specific T cells }\end{array}$ & $\begin{array}{l}\text { PTLD after solid organ } \\
\text { transplantation }\end{array}$ & $\begin{array}{l}\text { Not associated with graft rejection } \\
\text { No issue with HLA matching }\end{array}$ & $\begin{array}{l}\text { Complicated and time-consuming manufactur- } \\
\text { ing process } \\
\text { EBV-specific cytotoxic T cells } \\
\text { Long-term persistence of EBV-specific cytotoxic } \\
\text { T cells may not be achievable with continued } \\
\text { immunosuppression }\end{array}$ \\
\hline $\begin{array}{l}\text { Autologous EBV- } \\
\text { specific T cells }\end{array}$ & $\begin{array}{l}\text { EBV-lymphoproliferative diseases } \\
\text { with type II or III EBV latencies }\end{array}$ & Not associated with GVHD & $\begin{array}{l}\text { Genetic engineering of EBV-transformed } \\
\text { lymphoblastoid cell lines required }\end{array}$ \\
\hline
\end{tabular}

Abbreviations: DLI, donor lymphocyte infusion; EBV, Epstein-Barr virus; GVHD, graft-versus-host disease; HLA, human leukocyte antigen; HSCT, hematopoietic stem cell transplantation; MUD, matched unrelated donor; PTLD, post-transplantation lymphoproliferative diseases; UCB, umbilical cord blood. 
subtypes. $^{36}$ In 20 patients with relapsed EBV+ lymphomas, complete responses were observed in 4 of $6 \mathrm{NK} / \mathrm{T}$-cell lymphoma cases, 3 of 8 Hodgkin lymphoma cases, 2 of 4 cases of diffuse large B-cell lymphoma and 1 PTLD case. Because all of these lymphomas harbored type II latency EBV, the results indicate that $\mathrm{EBV}$-specific $\mathrm{T}$ cells are also effective for LPDs not expressing highly immunogenic EBV antigens, as observed in malignancies involving type III latency EBV.

Although these results are exciting, they must be considered in the context of other targeted therapies for these lymphomas (Table 2). Furthermore, the complicated logistics of manufacturing $\mathrm{EBV}+$ autologous $\mathrm{T}$ cells may limit the use of this form of treatment outside of clinical trials.

\section{METHYLATION OF EBV GENOME AS A POTENTIAL THERAPEUTIC TARGET}

In EBV-infected cells, the virus utilizes the expression of several different gene programs to control the expression of proteins on the infected cells. The regulation of expression is controlled by various epigenetic modifications to histone and DNA in the EBV genome. ${ }^{37}$ Methylation of the CpG islands of the major EBV latency promoter occurs in circulating EBV+ memory $\mathrm{B}$ cells, leading to type I latency. ${ }^{38}$ Similarly, CpG methylation of the EBV promoters also occurs in Burkitt lymphoma (type I latency) and Hodgkin lymphoma (type II latency). ${ }^{39}$ These epigenetic alterations suppress the expression of highly immunogenic EBV proteins characteristically found in the viral lytic phase, so that EBV-infected cells are able to evade immunosurveillance mechanisms. ${ }^{40}$

Epigenetic changes in the EBV genome may also indirectly lead to epigenetic alterations of EBV-infected cells. EBNAs and LMPs interact with many proteins involved in controlling host cell DNA and histone modifications. ${ }^{40}$ In neoplastic cells, these epigenetic changes repress the production of key tumor suppressors and contribute to the malignant phenotype.

The understanding of the epigenetic control of the latentlytic switch in the EBV genome provides the theoretical framework of the 'lytic-induction therapy. ${ }^{30}$ In this approach, drugs that potentially reverse epigenetic changes in the EBV genome are postulated to induce the virus to undergo lytic phase proliferation in tumor cells, thereby leading to the expression of viral thymidine kinase. Therefore, when the antiviral drug ganciclovir is administered, it is phosphorylated by the viral thymidine kinase and subsequently becomes toxic to the neoplastic cell containing the lytic virus. ${ }^{41}$ This concept had been tested in 15 patients with PTLD, B-cell, T-cell, NK-cell and Hodgkin lymphoma. ${ }^{42}$ Ten patients showed significant antitumor responses, and four patients achieved complete remission.

Another interesting observation was that the chemotherapeutic drug cyclophosphamide appeared to induce viral lytic phase in endemic Burkitt lymphoma. ${ }^{43}$ On the basis of this proposition, a phase I study recently evaluated the concomitant use of valacyclovir and cyclophosphamide in endemic Burkitt lymphoma and showed that this combination was safe. ${ }^{44}$ Further clinical testing of this concept is needed.

Although these results appear promising, they must be compared with emerging novel and targeted therapies for these lymphomas.

\section{ANTIVIRAL TREATMENT IN EBV+ LPD}

Except when used together with epigenetically active agents, ${ }^{41-44}$ antiviral drugs exhibit no direct effect on EBV+ LPD. However, when used prophylactically, antiviral drugs appear to suppress EBV replication and hence decrease the occurrence of PTLD after HSCT or solid organ allografting. ${ }^{45-48}$ Antiviral drugs also appear to be effective in suppressing EBV replication in immunocompetent subjects. ${ }^{49-51}$ Hence, in patients at high risk of EBV+ PTLD, the use of prophylactic antiviral drugs may be warranted.

\section{CONCLUSIONS}

In EBV+ LPD, EBV is an attractive therapeutic target. Cellular therapy targeting EBV is an important validation of the efficacy of the immune system against neoplastic cells. However, these strategies must be compared with the emerging availability of gene- or pathway-targeted therapies. Finally, the production of EBV-specific $\mathrm{T}$ cells must be streamlined to attain a more timely and affordable treatment.

\section{CONFLICT OF INTEREST}

The authors declare no conflict of interest.

1 Epstein MA, Achong BG, Barr YM. Virus particles in cultured lymphoblasts from Burkitt's lymphoma. Lancet 1964; 1: 702-703.

2 Cohen JI. Epstein-Barr virus infection. N Engl J Med 2000; 343: 481-492.

3 Bollard CM, Rooney CM, Heslop HE. T-cell therapy in the treatment of posttransplant lymphoproliferative disease. Nat Rev Clin Oncol 2012; 9: 510-519.

4 Babcock GJ, Thorley-Lawson DA. Tonsillar memory B cells, latently infected with Epstein-Barr virus, express the restricted pattern of latent genes previously found only in Epstein-Barr virus-associated tumors. Proc Natl Acad Sci U S A. 2000; 97: 12250-12255.

5 Babcock GJ, Decker LL, Freeman RB, Thorley-Lawson DA. Epstein-barr virus-infected resting memory $B$ cells, not proliferating lymphoblasts, accumulate in the peripheral blood of immunosuppressed patients. J Exp Med 1999; 190: 567-576.

6 Neparidze N, Lacy J. Malignancies associated with epstein-barr virus: pathobiology, clinical features, and evolving treatments. Clin Adv Hematol Oncol 2014; 12: 358-371.

7 Kaplan LD. HIV-associated lymphoma. Best Pract Res Clin Haematol 2012; 25: 101-117.

8 Rasche L, Kapp M, Einsele H, Mielke S. EBV-induced post transplant lymphoproliferative disorders: a persisting challenge in allogeneic hematopoetic SCT. Bone Marrow Transplant 2014; 49: 163-167.

9 Landgren O, Gilbert ES, Rizzo JD, Socié G, Banks PM, Sobocinski KA et al. Risk factors for lymphoproliferative disorders after allogeneic hematopoietic cell transplantation. Blood 2009; 113: 4992-5001.

10 Gustafsson A, Levitsky V, Zou JZ, Frisan T, Dalianis T, Ljungman P et al. Epstein-Barr virus (EBV) load in bone marrow transplant recipients at risk to develop posttransplant lymphoproliferative disease: prophylactic infusion of EBV-specific cytotoxic T cells. Blood 2000; 95: 807-814. 
11 Stevens SJ, Verschuuren EA, Pronk I, van Der Bij W, Harmsen MC, The $\mathrm{TH}$ et al. Frequent monitoring of Epstein-Barr virus DNA load in unfractionated whole blood is essential for early detection of posttransplant lymphoproliferative disease in high-risk patients. Blood 2001; 97: 1165-1171.

12 van Esser JW, Niesters HG, van der Holt B, Meijer E, Osterhaus AD, Gratama JW et al. Prevention of Epstein-Barr virus-lymphoproliferative disease by molecular monitoring and preemptive rituximab in high-risk patients after allogeneic stem cell transplantation. Blood 2002; 99: 4364-4369.

13 Kuehnle I, Huls MH, Liu Z, Semmelmann M, Krance RA, Brenner MK et al. CD20 monoclonal antibody (rituximab) for therapy of Epstein-Barr virus lymphoma after hemopoietic stem-cell transplantation. Blood 2000; 95 1502-1505.

14 Papadopoulos EB, Ladanyi M, Emanuel D, Mackinnon S, Boulad F, Carabasi $\mathrm{MH}$ et al. Infusions of donor leukocytes to treat Epstein-Barr virus-associated lymphoproliferative disorders after allogeneic bone marrow transplantation. N Engl J Med 1994; 330: 1185-1191.

15 Smith CA, Ng CY, Heslop HE, Holladay MS, Richardson S, Turner EV et al. Production of genetically modified Epstein-Barr virus-specific cytotoxic $\mathrm{T}$ cells for adoptive transfer to patients at high risk of EBV-associated Iymphoproliferative disease. J Hematother 1995; 4: 73-79.

16 Lacerda JF, Ladanyi M, Louie DC, Fernandez JM, Papadopoulos EB, O'Reilly RJ. Human Epstein-Barr virus (EBV)-specific cytotoxic T lymphocytes home preferentially to and induce selective regressions of autologous EBV-induced B cell lymphoproliferations in xenografted C.B-17 scid/ scid mice. J Exp Med 1996; 183: 1215-1228.

17 Heslop HE, Ng CY, Li C, Smith CA, Loftin SK, Krance RA et al. Long-term restoration of immunity against Epstein-Barr virus infection by adoptive transfer of gene-modified virus-specific T Iymphocytes. Nat Med 1996; 2: 551-555.

18 Roskrow MA, Suzuki N, Gan Yj, Sixbey JW, Ng CY, Kimbrough S et al. Epstein-Barr virus (EBV)-specific cytotoxic T lymphocytes for the treatment of patients with EBV-positive relapsed Hodgkin's disease. Blood 1998; 91: 2925-2934.

19 Rooney CM, Smith CA, Ng CY, Loftin SK, Sixbey JW, Gan Y et al. Infusion of cytotoxic $T$ cells for the prevention and treatment of Epstein-Barr virusinduced lymphoma in allogeneic transplant recipients. Blood 1998; 92: 1549-1555.

20 Heslop HE, Slobod KS, Pule MA, Hale GA, Rousseau A, Smith CA et al. Long-term outcome of EBV-specific T-cell infusions to prevent or treat EBV-related lymphoproliferative disease in transplant recipients. Blood 2010; 115: 925-935.

21 Doubrovina E, Oflaz-Sozmen B, Prockop SE, Kernan NA, Abramson S, Teruya-Feldstein $\mathrm{J}$ et al. Adoptive immunotherapy with unselected or EBV-specific T cells for biopsy-proven EBV+ lymphomas after allogeneic hematopoietic cell transplantation. Blood 2012; 119: 2644-2656.

22 Chan TS, Hwang YY, Gill H, Au WY, Leung AY, Tse E et al. Post-transplant lymphoproliferative diseases in Asian solid organ transplant recipients: late onset and favorable response to treatment. Clin Transplant 2012; 26: $679-683$.

23 Evens AM, David KA, Helenowski I, Nelson B, Kaufman D, Kircher SM et al. Multicenter analysis of 80 solid organ transplantation recipients with post-transplantation lymphoproliferative disease: outcomes and prognostic factors in the modern era. J Clin Oncol 2010; 28: 1038-1046.

24 Emanuel DJ, Lucas KG, Mallory GB Jr, Edwards-Brown MK, Pollok KE, Conrad PD et al. Treatment of posttransplant lymphoproliferative disease in the central nervous system of a lung transplant recipient using allogeneic leukocytes. Transplantation 1997; 63: 1691-1694.

25 Haque T, Taylor C, Wilkie GM, Murad P, Amlot PL, Beath S et al. Complete regression of posttransplant lymphoproliferative disease using partially HLA-matched Epstein Barr virus-specific cytotoxic T cells. Transplantation 2001; 72: 1399-1402.

26 Comoli P, Labirio M, Basso S, Baldanti F, Grossi P, Furione M et al. Infusion of autologous Epstein-Barr virus (EBV)-specific cytotoxic T cells for prevention of EBV-related lymphoproliferative disorder in solid organ transplant recipients with evidence of active virus replication. Blood 2002; 99: 2592-2598.

27 Savoldo B, Goss JA, Hammer MM, Zhang L, Lopez T, Gee AP et al. Treatment of solid organ transplant recipients with autologous Epstein Barr virus-specific cytotoxic T lymphocytes (CTLs). Blood 2006; 108 2942-2949.

28 Comoli P, Maccario R, Locatelli F, Valente U, Basso S, Garaventa A et al. Treatment of EBV-related post-renal transplant lymphoproliferative disease with a tailored regimen including EBV-specific T cells. Am J Transplant 2005; 5: 1415-1422.

29 Haque T, Wilkie GM, Taylor C, Amlot PL, Murad P, Iley A et al. Treatment of Epstein-Barr-virus-positive post-transplantation lymphoproliferative disease with partly HLA-matched allogeneic cytotoxic T cells. Lancet 2002; 360: 436-442.

30 Haque T, Wilkie GM, Jones MM, Higgins CD, Urquhart G, Wingate P et al. Allogeneic cytotoxic T-cell therapy for EBV-positive posttransplantation lymphoproliferative disease: results of a phase 2 multicenter clinical trial. Blood 2007; 110: 1123-1131.

31 Barker JN, Doubrovina E, Sauter C, Jaroscak JJ, Perales MA, Doubrovin M et al. Successful treatment of EBV-associated posttransplantation lymphoma after cord blood transplantation using third-party EBV-specific cytotoxic T lymphocytes. Blood 2010; 116: 5045-5049.

32 Vickers MA, Wilkie GM, Robinson N, Rivera N, Haque T, Crawford DH et al. Establishment and operation of a Good Manufacturing Practice-compliant allogeneic Epstein-Barr virus (EBV)-specific cytotoxic cell bank for the treatment of EBV-associated lymphoproliferative disease. $\mathrm{Br} J$ Haematol 2014; 167: 402-410.

33 Sing AP, Ambinder RF, Hong DJ, Jensen M, Batten W, Petersdorf E et al. Isolation of Epstein-Barr virus (EBV)-specific cytotoxic T lymphocytes that lyse Reed-Sternberg cells: implications for immune-mediated therapy of EBV+ Hodgkin's disease. Blood 1997; 89: 1978-1986.

34 Bollard CM, Aguilar L, Straathof KC, Gahn B, Huls MH, Rousseau A et al. Cytotoxic T lymphocyte therapy for Epstein-Barr virus+ Hodgkin's disease. J Exp Med 2004; 200: 1623-1633.

35 Savoldo B, Huls MH, Liu Z, Okamura T, Volk HD, Reinke P et al. Autologous Epstein-Barr virus (EBV)-specific cytotoxic $T$ cells for the treatment of persistent active EBV infection. Blood 2002; 100: 4059-4066.

36 Bollard CM, Gottschalk S, Torrano V, Diouf O, Ku S, Hazrat Y et al. Sustained complete responses in patients with lymphoma receiving autologous cytotoxic $T$ lymphocytes targeting Epstein-Barr virus latent membrane proteins. J Clin Oncol 2014; 32: 798-808.

37 Tempera I, Lieberman PM. Epigenetic regulation of EBV persistence and oncogenesis. Semin Cancer Biol 2014; 26: 22-29.

38 Robertson KD, Ambinder RF. Methylation of the Epstein-Barr virus genome in normal lymphocytes. Blood 1997; 90: 4480-4484.

39 Robertson KD, Manns A, Swinnen LJ, Zong JC, Gulley ML, Ambinder RF. $\mathrm{CpG}$ methylation of the major Epstein-Barr virus latency promoter in Burkitt's lymphoma and Hodgkin's disease. Blood 1996; 88: 3129-3136.

40 Kenney SC, Mertz JE. Regulation of the latent-lytic switch in Epstein Barr virus. Semin Cancer Biol 2014; 26: 60-68.

41 Ghosh SK, Perrine SP, Williams RM, Faller DV. Histone deacetylase inhibitors are potent inducers of gene expression in latent EBV and sensitize lymphoma cells to nucleoside antiviral agents. Blood 2012; 119: 1008-1017.

42 Perrine SP, Hermine O, Small T, Suarez F, O'Reilly R, Boulad F et al. A phase $1 / 2$ trial of arginine butyrate and ganciclovir in patients with Epstein-Barr virus-associated lymphoid malignancies. Blood 2007; 109: 2571-2578.

43 Tang W, Harmon P, Gulley ML, Mwansambo C, Kazembe PN, Martinson F et al. Viral response to chemotherapy in endemic burkitt lymphoma. Clin Cancer Res 2010; 16: 2055-2064.

44 Olson D, Gulley ML, Tang W, Wokocha C, Mechanic O, Hosseinipour M et al. Phase I clinical trial of valacyclovir and standard of care cyclophosphamide in children with endemic Burkitt lymphoma in Malawi. Clin Lymphoma Myeloma Leuk 2013; 13: 112-118.

45 Darenkov IA, Marcarelli MA, Basadonna GP, Friedman AL, Lorber KM, Howe JG et al. Reduced incidence of Epstein-Barr virus-associated posttransplant lymphoproliferative disorder using preemptive antiviral therapy. Transplantation 1997; 64: 848-852.

46 Malouf MA, Chhajed PN, Hopkins P, Plit M, Turner J, Glanville AR. Anti-viral prophylaxis reduces the incidence of lymphoproliferative disease in lung transplant recipients. J Heart Lung Transplant 2002; 21: 547-554.

47 Funch DP, Walker AM, Schneider G, Ziyadeh NJ, Pescovitz MD. Ganciclovir and acyclovir reduce the risk of post-transplant lymphoproliferative disorder in renal transplant recipients. Am J Transplant 2005; 5: 2894-2900.

48 Hierro L, Díez-Dorado R, Díaz C, De la Vega A, Frauca E, Camarena C et al. Efficacy and safety of valganciclovir in liver-transplanted children infected with Epstein-Barr virus. Liver Transp/ 2008; 14: 1185-1193. 
49 Gill H, Hwang YY, Chan TS, Pang AW, Leung AY, Tse E et al. Valganciclovir suppressed Epstein Barr virus reactivation during immunosuppression with alemtuzumab. J Clin Virol 2014; 59: 255-258.

50 Hsu JL, Glaser SL. Epstein-barr virus-associated malignancies: epidemiologic patterns and etiologic implications. Crit Rev Oncol Hematol 2000; 34: 27-53.

51 Kanegane H, Nomura K, Miyawaki T, Tosato G. Biological aspects of Epstein-Barr virus (EBV)-infected lymphocytes in chronic active EBV infection and associated malignancies. Crit Rev Oncol Hematol 2002; 44: 239-249. (c) (1) $(\Theta)$ This work is licensed under a Creative Commons Attribution-NonCommercial-NoDerivs 3.0 Unported License. The images or other third party material in this article are included in the article's Creative Commons license, unless indicated otherwise in the credit line; if the material is not included under the Creative Commons license, users will need to obtain permission from the license holder to reproduce the material. To view a copy of this license, visit http://creativecommons.org/licenses/by-nc-nd/3.0/ 